\title{
Spotlight on UK artisan entrepreneurs' situated collaborations - through the lens of entrepreneurial capitals and their conversion
}

\begin{abstract}
Purpose - The article's purpose is to demonstrate how UK artisan entrepreneurs organise entrepreneurial activities within the context of a creative industry organisation. The research asks how artisan entrepreneurs draw on contexts to organise entrepreneurial activities. The article investigates how these entrepreneurs organise collaborative business solutions through the lens of entrepreneurial capitals and their conversion. Design/methodology/approach - The research employs a phenomenological approach to analyse the situated entrepreneurial activities of artisan entrepreneurs. Ethnographic methods assisted in capturing these activities.

Findings - The findings demonstrate the context dependent collaborative business solutions by artisan entrepreneurs. Such solutions emerge from the interplay of the materiality of buildings, social relations management and personal resources. This materiality facilitates creative forms of social relations management for entrepreneurial activities between artisan entrepreneurs.
\end{abstract}

Originality - The detailed discussion of how artisan entrepreneurs organise entrepreneurial activities individually and collaboratively sheds light on dynamic micro-processes in context. The lens of entrepreneurial capitals and their conversion for these micro-processes integrates the literature on capital conversions with context as the main contribution to theory. This lens allows to home in on social relations and material environment management adding more fine-grained insights into how these micro-exchangeprocesses work. These insights contribute to the literature on artisan entrepreneurship in the creative industries and entrepreneurship and context.

Practical implications - The discussed entrepreneurial collaborative solutions are beneficial for many entrepreneurs in fragmented working conditions.

Keywords Artisan entrepreneur, Entrepreneurship, Bourdieu, Capitals, Context, Craft. Paper type Research paper 


\section{Introduction}

The creative economy is an important global driver of economic growth, doubling in size between 2002 and 2015 worldwide, reaching £101.5 billion turnover in the UK in 2018 (UNCTAD, 2018). This sector is known for high labour market fragmentation, with nearly one third of workers being self-employed with no staff, many in micro-businesses (Department for Business, Energy and Industrial Strategy, 2018). Moreover, these fragmented working conditions are more common amongst creative industries professionals (Dellot and Wallace-Stephens, 2017), rendering this sector a good example to study further their solutions for managing this fragmentation relevant for the future of work.

The current literature suggests that we know relatively little about how creative entrepreneurs develop businesses and the role of context (De Klerk, 2015; Townley et al., 2009). Recent research on creative industries identified the wide variety of capital involved in creative production as a significant feature of this sector (Pick et al., 2015, Townley et al., 2009), which requires fresh approaches to research and theory building this article addresses (Pick et al., 2015). Considering their socio-economic significance (UNCTAD, 2018), a detailed insight into how these entrepreneurs organise doing business - the micro-processes - would be valuable. These insights would allow policy makers to learn from creative entrepreneurs their solutions for managing fragmented ways of earning a living, to effectively inform business support policies. Similarly, such insights into creative solutions for business development would benefit creative entrepreneurs by generating more income.

Craft and artisan entrepreneurs constitute a subsector in creative industries (Pret and Cogan, 2019), and for the remainder of this article "artisan entrepreneurs" is the label used for both of these groups. Artisan entrepreneurs create tangible products manually (Arias and Cruz, 2019) with support from simple machines or technology, like functional household goods or jewellery, or specialised food, such as artisan bakery or beers. Glass, silver, cloth and clay are typical materials used. Entrepreneurship research has only recently paid more academic attention to artisan entrepreneurs (e.g. Bell et al., 2018; Danson et al., 2015; Teixeira and Ferreira, 2019; Ratten et al., 2019).

Within such artisan entrepreneurial activities, this research explores the role of social relations and materiality for organising within a small organisation ('The Creative'). The research seeks to answer the question: "How do artisan entrepreneurs draw on contexts to organise entrepreneurial activities?" by reconstructing what shapes entrepreneurial activities in a particular organisation (Welter et al., 2019). This question focuses attention to- 
wards explaining how artisan entrepreneurs organise their daily entrepreneurial activities, with a focus on social relations and materiality as influencing elements in the context. Thus, the answer investigates micro-processes in a studio within the UK creative industry. The research analyses daily entrepreneurial activities through the lens of situated entrepreneurial capitals (Hill, 2018). These entrepreneurial capitals consist of social relations and assets, which are applied to entrepreneurial activities.

The article makes several theoretical contributions: first, it explains interpersonal capital conversions ('conversion' explains the transformation of assets' and social relations' context dependent values), extending the existing views on intra-personal conversions (Pret et al., 2016) to the interpersonal level; it locates capital conversions at the meso-level. Second, it links the research streams of entrepreneurship and context with capital conversions and practice theory. Third, its practical implications focus on situated, creative collaborative solutions, which are suitable for many service entrepreneurs, illustrated through the study of the micro-processes of three artisan entrepreneurs.

\section{Literature review and conceptual framework}

Bourdieu's practice theory applications in entrepreneurship research

Practice theories are seen as a subset within process-relational theories, which home in on how human beings and their relations are integrated into dynamic processes (Nicolini, and Monteiro, 2017; Langley and Tsoukas, 2017). Process-relational thinking adds into process analysis the dynamic element of social interactions between people, processes and institutions and offers more insights into how outcomes are achieved (Langley and Tsoukas, 2017). Practice theory has many theoretical foundations (e.g., Bourdieu, 1990; Giddens, 1990; Schatzki, 2002). This article's approach is rooted in Bourdieu's approach to 'practice'. The term 'practice' is employed as a heuristic device to increase understanding of organised, connected and dynamic sets of situated activities mediated by the sociomaterial context (Gherardi, 2012). Practices are meaningful re-creating activities, ranging from simple sets - for example, buying a cinema ticket - to more complex ones, such as starting a business. Agents execute practices and enact social macrostructures (Johannisson, 2018; Sklaveniti and Steyaert, 2020); agents link personal structure and macrostructures in their practices. Therefore, empirical studies into practices contribute to bridging the divide between macro-level studies on policy and support macrostructures - for example of regional economies - and micro-level studies illustrating the mindset and behaviours of entrepreneurs (Thompson et al., 2020). 
Within Bourdieu's practice theory 'field' denotes an arena of power; 'field agents' (individuals who carry out practices) are situated in field positions they re-construct, temporarily to allow for power and status (Bourdieu, 1986, 1990). Fields are particular to an industry and a specific location; fields have fuzzy boundaries and rules that entrepreneurs only acquire over time through running their own businesses (Hill, 2018). Capitals (cultural, economic, social, symbolic), meanwhile, are vehicles to negotiate power positions in a field and are thus field-dependent; consequently, they rarely have universal value outside of a specific context. For Bourdieu, cultural capital exists in three-forms: objectified, for example, in pieces of art; institutionalised, for example through formal education and accreditations (symbolising authority and competence); and embodied, culturally informed ways of behaviour, including sector specific ways of doing business. Social capital refers to an individual's network of social exchange relations. Symbolic capital refers to reputational assets individuals can draw on to position themselves. Economic capital (financial assets) is not the most important asset for business. Personal structure, the interconnected experiences, knowledge, skills, dispositions and mindsets individuals draw on for behaviour, is rarely considered (Bourdieu, 1986, 1990).

Studies applying Bourdieu's concepts are increasingly popular (e.g., Sklaveniti and Steyaert, 2020; Reid, 2020). While social capital has been frequently discussed in entrepreneurship research (Gedaljovic et al., 2013; McKeever et al., 2014), and particularly in ethnic minority entrepreneurship research (Ram et al., 2008; Vershinina et al., 2011), the concept remains ambiguous. Too often, social capital is applied uncritically denoting contacts held individually, conceptualising a static perspective of having contacts. Symbolic capital has gained prominence in explaining social positions and lived experiences (Pret et al., 2016; Reid, 2020; Vershinina and Rodgers, 2019) and gaining legitimacy in fields (De Clerq and Voronov, 2009). While many researchers believe context impacts on entrepreneurial behaviour (e.g. Zahra et al., 2014), the actual understanding of how 'context' influences doing business has been analysed in more depth in the last decade, following numerous calls for this kind of research (Welter and Gartner, 2016). Hill (2018), further clarifying Bourdieu's concepts for entrepreneurship research through an intermediary framework, argues that social relations and capitals are maintained at the meso-level contrasting views, which regard capitals owned by individuals (Payne et al., 2011). Thus, only those aspects of capitals brought into doing business are relevant, requiring an additional label of 'entrepreneurial capitals'. 
The resource-based view (e.g. Wernerfelt, 1984) treats resources as related to context [used in the singular], differentiating social, economic, and other context types (Welter et al., 2019). This view sees context as external to individuals (Afreh et al., 2019). The process-relational lens, however, regards 'contexts' (in the plural), as relational, because contexts are continuously recreated by individuals in different ways at different times, dependent on the activity they are engaged in (Welter and Gartner, 2016). For example, one artisan entrepreneur might engage with element ' $A$ ' of an organisation's material environment in producing an artwork, but draw on element ' $B$ ' when organizing a workshop, dependent on which aspects of the personal structure they draw on to do business. Thus, the process-relational lens overcomes the above 'static' nature of the research rooted in the resource-based view.

Sociomateriality is widely used in sociology and management studies investigating business practices (Gherardi, 2012; Orlikowski, 2007); it offers a helpful lens for deeper analysis of dynamic micro-processes. While analytically the 'social' and the 'material' are separated, they are entangled in agency. Thus, all practices are seen as sociomaterial in nature (Orlikowski, 2007), without giving social relations a priority over the material. 'Contexts' thus denotes the inseparable nature of the social and the material.

\section{Capital conversions applications in entrepreneurship studies}

Capital conversions have been discussed mostly at a conceptual level (Hill, 2018; Pret et al., 2016), to illustrate entrepreneurial learning (Karatas-Özkan, 2011) to explain entrepreneurial start-up behaviour and life-style enterprising (Reid, 2020; Vershinina et al., 2011) or to study behaviours of artisan and cultural entrepreneurs (Pret et al., 2016; Scott, 2012). While context has been touched upon in the studies on embeddedness, the analyses discuss notions of a static exchange with context. Context is seen as external to the individual (Welter et al., 2019). The majority of studies discusses conversion of up to two capitals (Pret et al., 2016). Studies on impact of intrapersonal conversions discuss gaining higher value networks leading to increased economic assets through investments into education, converting industry experience (cultural capital) to enhanced professional reputation (symbolic capital) and transforming prestige as a professional (symbolic capital) to more resourceful networks and exclusive education (Bitektine, 2011; McLeod et al., 2009; Reid, 2020). Pret et al.'s (2016) excellent detailed review of capital conversion research for entrepreneurship literature brings together many findings this article can point to (2016). However, these authors do not differentiate the value of these theoretical approaches and epistemological insights or discuss how context influences capital conversions. 


\section{Artisan entrepreneurship as context}

'Artisan entrepreneurship' is the umbrella term for craft and artisan entrepreneurship (Pret and Cogan, 2019). 'Craft' denotes in this article the contrast embedded in this kind of work to mass - manufactured goods, related to the predicted likely impact of technological advancements on the need of human labour for the future of work. (Bell et al., 2019; OECD, 2019). Artisan entrepreneurs create tangible small-batch or unique products manually supported by tools (Arias and Cruz, 2019), suitable for everyday use. A growing number of sector studies explore brewing, food or textile industry entrepreneurship (Ratten et al., 2019), but few researchers study traditional craft sectors, including pottery, drawing and glass work (but see Hassan, et al., 2017; Marques et al., 2019). In addition, research on artisan entrepreneurs via Bourdieu's capitals is limited and has most frequently investigated access to financial capital (Pret et al., 2016), followed by discussions of human, social and symbolic capital (Flanagan et al., 2018; Pret et al., 2016).

The sector is known to have fragmented approaches to income generation (Flanagan et al., 2018; Parry, 2010), which include combining part-time work with self-employment. Research has discussed co-operative behaviours, most commonly, networking and collaborations, even with competitors (Bengtsson and Kock, 2000; Kuhn and Galloway, 2015). Conflicting views exist to what extent these behaviours are solely an expression of more mutually supportive craft "communities" sharing a passion for the craft they pursue (Marques et al., 2019; Pret et al., 2016). Others have found such "co-opetition" behaviour is simply undertaken for strategic reasons (Bengtsson and Kock, 2000). Strategic reasons include creating competitive advantage, for example, achieving cost savings through marketing complementary offers together, sharing networks and temporary partnerships for competing with rivals as a group (Flanagan et al., 2018; Kuhn and Galloway, 2015), or simply a survival strategy (Scott, 2012).

Studying these creative forms of collaborations by artisan entrepreneurs could reveal insights relevant for managing the increasing fragmentation of labour markets in other industries (OECD, 2019). Thus, artisan entrepreneurial activities in creative industry sites offer a context for a deeper understanding of situated work organisation.

\section{Conceptual framework}

Linking these literature strands, this article investigates situated entrepreneurial activities as units of analysis, focusing on how agency recreates contexts and enacts sociomateriali- 
ty (Gherardi, 2012; Orlikowski, 2007), following calls to apply multi-layered approaches (Wigren et al., 2019). The research asks the following research question: How do artisan entrepreneurs draw on contexts to organise entrepreneurial activities? This investigation focuses on social relations and materiality as contexts. The enactment of this sociomateriality in entrepreneurial activities is illustrated through findings about three artisan entrepreneurs sharing a studio, called studio X, located in a UK creative industry organisation, the Creative. The analysis considers the 'material' through artefacts in a studio and the organisation the Creative (including buildings, tools and materials)(see Figure 1). The 'social' refers to social relations between these three and one other artisan entrepreneur that impact on entrepreneurial activities and the social interactions with customers within studio $X$ and the Creative.

The research question is divided into sub-questions:

- How does the 'material' of the Creative organisation and studio $X$ directly affect entrepreneurial activities?

- How does the 'material' impact on social relations within the Creative? and as a consequence,

- How do these social relations influence the organisation of entrepreneurial activities?

Situated entrepreneurial capitals (Hill, 2018) are the chosen lens to analyse ongoing micro exchange processes constituting entrepreneurial activities. These entrepreneurial capitals are only those elements of capitals (Bourdieu, 1986, 1990) that are brought into the social processes of 'doing business', and consequently obtain particular relevance. These capitals are differentiated as entrepreneurial economic, social, symbolic and cultural (following Bourdieu, 1986). Entrepreneurs relationally re-create entrepreneurial capitals through situated practices (Reid, 2020). They link societal macrostructures with their personal structure (the set of skills, experiences, and knowledge held by the individual) in their agency. For example, money in a bank account, generating interest, and not being invested in, or gaining interest for investment, in the business, is not entrepreneurial financial capital, as it is not integrated into the social relations of 'doing business' (Hill, 2018).

$<$ about here Figure $1>$ 


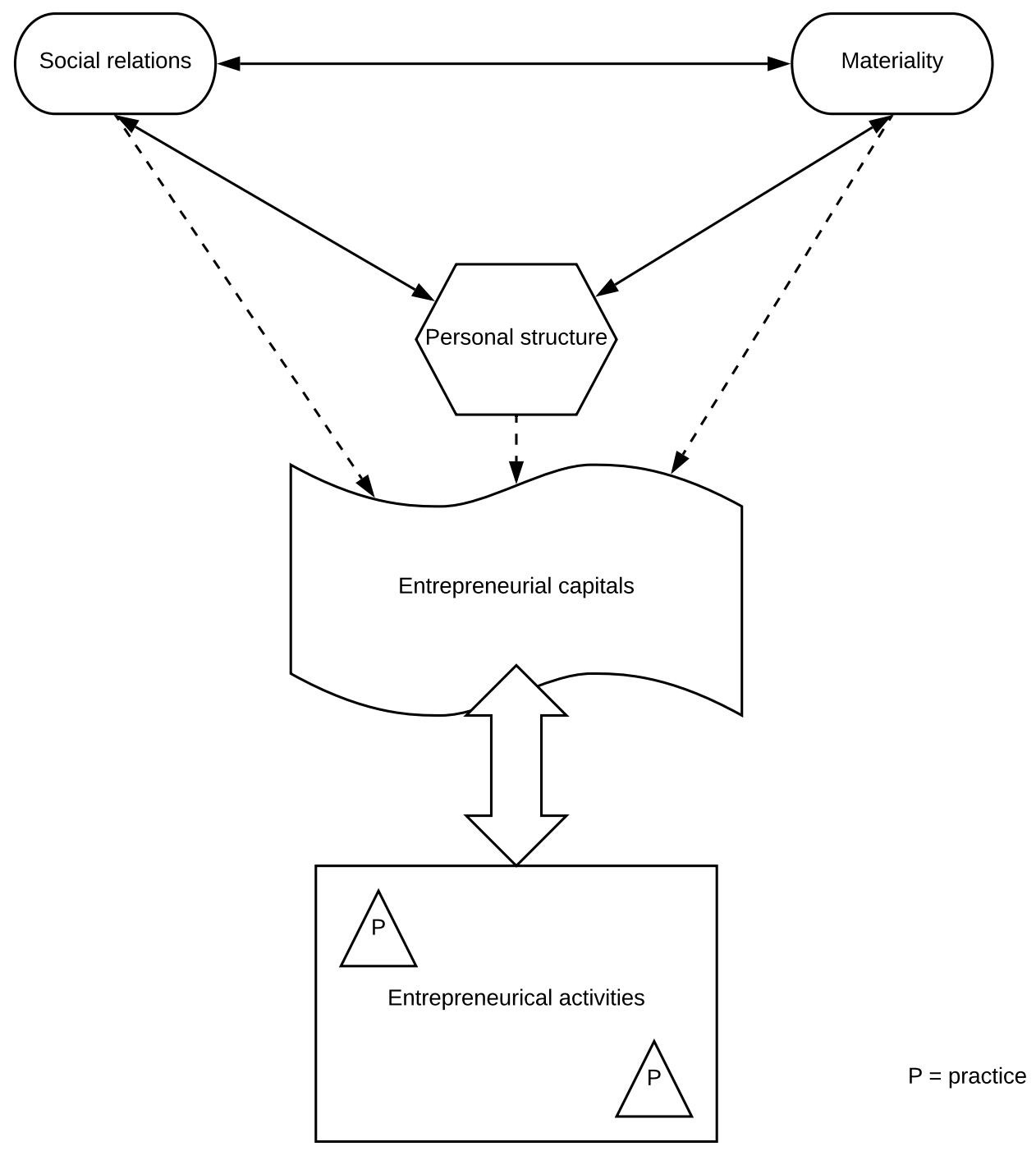

Figure 1 Conceptual framework

\section{Methodology}

Research approach, design and positionality

The research study was inspired by the creative solutions found by artisan entrepreneurs working within a creative industry organisation (The Creative) the author knew before research start. This article used an embedded case study, as it combines data sources to capture the daily situated reality of artisan entrepreneuring. The case study concerns three artisan entrepreneurs, Ashley, Billie, and Casey (gender neutral names) sharing one studio (studio $X$ from now onwards), located within the Creative. Their case was chosen as a "particularly revelatory" case (Eisenhardt and Graebner, 2007, p. 27), because their situated everyday activities demonstrate nuanced social relations and emerg- 
ing creative strategies for income generation typical of artisan entrepreneurs' work. Yet, their strategic management is more developed than most cases written about.

The article adopts a phenomenological approach to reconstruct situated entrepreneurial activities (Pret et al., 2016). The research presents the artisan entrepreneurs' viewpoints of situated practices and practical sense-making, grounded in their interests. Their narratives are triangulated with insights of close stakeholders within the Creative. Indeed, part of the intention of this research was to give voice to artisan entrepreneurs' daily activities and emerging strategising. Consequently, this research assumes events only gain relevance in the minds of individuals once they have been giving a meaning in a particular context (Berger and Luckmann, 1966; Cunliffe and Scaratti, 2017). For these reasons, the unit of analysis is situated entrepreneurial activities.

To capture these contingent meanings in a particular location and the interplay of entrepreneurial activities and the social and material contexts (Orlikowski, 2007), the research design builds towards the case study as revealed to the researcher through the interviews and observations. It includes methods suitable for capturing verbal behaviour (semi-structured interviews) and overt behaviour (observations). The research regards the entrepreneurial activities in studio $X$ as a materialisation of negotiations of social relations and societal macrostructures (Gherardi, 2012).

The researcher regularly visited the site for 15 months, at least monthly, sometimes weekly, for research purposes, and took part in craft workshops run in studio $X$. The researcher is known to the resident artisan entrepreneurs as a former service entrepreneur, an academic researcher and a customer. The researcher's positionality (Kirstetter, 2012) relative to the Creative is an influential factor in generating assumptions of some shared access to the world of micro-entrepreneurs in UK society, increasing openness during interviews.

\section{Data collection}

To offer a methodological fit, the research applies ethnographic methods (Berglund and Wigren, 2014), drawing on three data sources: semi-structured interviews; observation through workshop attendance in the role of customer; and observation notes - to capture mundane entrepreneurial activities and their ascribed meanings. The process-relational lens applied in this research (Johannisson, 2018) requires open ways to capture all possibly details of daily entrepreneuring to establish meaning. Thus, the data collection instruments need to be able to apprehend as much data as possible. The combination of semistructured interviews, workshop participation as action research and observations provide 
different angles to capture all possible insights. These kinds of results offer confidence in having captured the most significant aspects of situated entrepreneuring. While indicative interview questions were a starting point, the researcher let the participants develop the agenda turning the research interview into a dialogue (Cunliffe and Scaratti, 2017).

The research began with interviewing Ashley, Billie and Casey, who were sharing one studio, studio X. Overall, 30 visits, six formal observations (where the researcher sat near studio $X$ to watch activities in around it) and participation in five workshops as a customer form the materials. Subsequently, interviews with three stakeholders from the Creative (site manager, resident artisan entrepreneur Finley and a cafe staff member) and further informal studio visits helped to triangulate the observation and interview insights. Finally, artisan entrepreneurs Finley and Billie were interviewed a second time.

All interviews were conducted within the boundaries of the Creative; they lasted between 1.75 and 2.5 hours, were recorded and transcribed verbatim. The raw data includes over 100,000 words, of which 78,000 are from interview transcripts from eight interviews, notes on site visits and workshop participation (lasting over 15 hours), followed by pre- and post-workshop visits; and analytical research notes. The investigation includes findings from website and social media analysis and notes of short conversations with research participants when the researcher was on site as a paying customer to triangulate observations and interview statements.

While this research is based on one institutional case and one studio with its tenants, the findings on the micro-processes are used as indicative examples to demonstrate the applicability of wider theoretical issues. Indeed, this article's research does not claim to offer widely generalisable insights. Rather, it shows how micro-processes are emerging in situ and how the lens of interpersonal entrepreneurial capital conversions can add insights for understanding entrepreneurial processes.

\section{Data analysis}

The research process aimed to discover situated patterns of entrepreneurial activities and how contexts (focused on materiality and social relations) impact on these activities. Initially, the in-depth analysis of the raw data was actor-focused, aimed at creating an outline of the artisan entrepreneurs' professional history, resources and social relations. The analysis began with coding transcripts to identify how artisan entrepreneurs' relationships had developed. The questions asked in the interview guided the coding; additional codes were collected during this phase for additional themes raised by the artisan entrepreneurs; then, 
resultant codes were applied to all texts (See Table 1). In the open-ended inductive analysis, the researcher moved between texts, literature, emerging themes and theory (Vershinina et al., 2011). Such recursive processes aimed to move between first and second order thematic categories to find iterative patterns and nuanced differences in entrepreneurial activities to develop theory (Eisenhardt and Graebner, 2007).

\begin{tabular}{|c|c|c|}
\hline \multicolumn{3}{|c|}{ Table 1 Coding scheme } \\
\hline First order concepts & Second order themes & $\begin{array}{l}\text { Application of Bourdieu's (1990) and Hill's } \\
\text { (2018) concepts }\end{array}$ \\
\hline Life experiences & \multirow[t]{3}{*}{ Experiences prior to starting this business } & \multirow[t]{4}{*}{ Personal structure } \\
\hline Work experiences & & \\
\hline $\begin{array}{l}\text { Previous self-employment / business } \\
\text { experience }\end{array}$ & & \\
\hline Beliefs, attitudes, traits & Mindsets and dispositions & \\
\hline Education, training and accreditations & \multirow[t]{2}{*}{ Competences and abilities } & \multirow{4}{*}{$\begin{array}{l}\text { Entrepreneurial cultural capitals: institutional } \\
\text { embodied and objectified }\end{array}$} \\
\hline Skills and knowledge & & \\
\hline Customs, ways of doing and talking & (Learned) behaviours & \\
\hline $\begin{array}{l}\text { Pieces of art, objects; tangible goods of } \\
\text { own production }\end{array}$ & Symbols of authority and competence & \\
\hline Appearances in media (newspapers, TV) & \multirow[t]{2}{*}{ Communicating the value and views } & \multirow[t]{3}{*}{ Entrepreneurial symbolic capital } \\
\hline Exhibitions & & \\
\hline Gaining feedback on social media etc. & Others recognising the work & \\
\hline Parental support in the business & \multirow[t]{2}{*}{ Social relations with family relevant for the business } & \multirow[t]{4}{*}{ Entrepreneurial social capital } \\
\hline Spousal support in the business & & \\
\hline $\begin{array}{l}\text { Friends and other artists' support in the } \\
\text { business }\end{array}$ & \multirow[t]{2}{*}{ Peer support relevant for the business } & \\
\hline Membership of networks on - and offline & & \\
\hline $\begin{array}{l}\text { Money in the bank and invested in the } \\
\text { business }\end{array}$ & \multirow[t]{2}{*}{ Finance brought into the business } & \multirow[t]{3}{*}{ Entrepreneurial economic capital } \\
\hline $\begin{array}{l}\text { Income generated through employment } \\
\text { outside and invested in the business }\end{array}$ & & \\
\hline Money generated throughs sales & Cash generated through the business & \\
\hline
\end{tabular}


Through taking part in several craft workshops the researcher discovered the helpfulness of the lens of inter-entrepreneur capital conversions in their significance: During workshops, artisan entrepreneur Finley from a different studio, came in. Reasons included to chat with the other artisan entrepreneurs, but most often to pick up some of the products Casey had processed in one of the machines owned by the studio X occupants. Neither of the artisan entrepreneurs mentioned these close collaborations. This omission showed the limitations of the conscious awareness of the significance of the social relations with Finley, and identified the need to look closer at cross-studio professional interactions. Subsequently, all raw data were again read for indications of sharing any material resources and possible collaborations. The researcher returned to the Creative as a customer to assess the adequateness of the conclusions drawn, to ensure reliability of second order codes, observe and check interpretations in face to face discussion. Lastly, the researcher further aggregated the thematic codes into a framework that relates the lens of entrepreneurial capitals to the ongoing business activities to underpin the analysis. The researcher must acknowledge that the pre-existing knowledge of entrepreneurial capitals concepts might have influenced the focus of the research coding at the last stage; however, their significance emerged from the data analysis.

\section{Findings}

The case study artisan entrepreneurs Ashley, Billie and Casey moved together into the largest ground floor studio $X$ in 2016 for strategic reasons, to have more space and offer workshops (Flanagan et al., 2018). Before this move, they had been in two different studios for 8 years within the Creative and had not formally collaborated; however, resident artist entrepreneur Finley and Casey had previously cooperated.

Studio $X$ has two parts: the front shop area, where the artists' works and some additional goods are for sale. The second, larger part, functions as "workspace" and workshop area. ${ }^{1}$ The historic site making up the Creative is managed by the local town council; use and alterations to the studio spaces is restricted by Grade 2 listed building regulations. The Creative is open 7 days a week. It has a modern building with a museum, offices, shop and cafe; and eleven studios rented to artists in the historic buildings. Tenants are contractually obliged to be in their studios for at least two weekdays and three out of four weekends per month.

\footnotetext{
1 Details of the Creative, studio space $X$ and the artisan entrepreneurs are deliberately vague to ensure anonymity. 
When moving into studio $X$, the three artisan entrepreneurs formed a limited company, which takes income made by every artists and pays it to each after deduction of shared expenses (such as rent and bills). Billie explains: "It just seemed the easiest way. We were all doing our own accounts and self-employed, and we decided to have company $\mathrm{K}$ because we wanted to have a brand that was us...calling yourself an artist, and that's not what we really wanted to do, there's plenty of that in the craft industry. We just wanted to be company K." This quote illustrates how the legal form of a limited company acts as an umbrella, named company $\mathrm{K}$, and projects a coherent image for the variety of business activities offered by each artisan entrepreneur.

Studio $X$ enables dense social relations: The artisan entrepreneurs are together in a small space and spend time working next to each other. Ashley's quotes illustrate this insight: "But really the best part of it [creating a new service relating to a deceased's ashes] was bringing the three of us together with our different skills and we decided to work together." "So we're just a team. We'll talk about things - it's so important, we're in the space face-to-face together all the time."

As pointed out above, the three were in two different studios for over 8 years within the Creative only meters apart before the move and did not form such close working relationships. The next quote indicates the significance of the material context for entrepreneurial activities: "we're in the space face-to-face". The opportunities offered by studio $X$ to sit and work alongside each other simultaneously has enabled the team creation. These insights indicate how the material has significantly shaped the social (Gherardi, 2012); the subsequently developing social relations materialised in forming company $\mathrm{K}$ with three directors (Ashley, Billie, Casey). Thus, the company formation is an enactment of sociomateriality (Orlikowski, 2007) and a form of co-opetition (Flanagan, 2018).

\section{Intrapersonal capital conversions as situated entrepreneurial practices}

This research found numerous examples of intrapersonal entrepreneurial capital conversions for Ashley, Billie and Casey in studio X, in line with findings by Pret et al. (2016), illustrated indicatively in Table 2 (see appendix). Some of these entrepreneurial activities are iterative patterned activities, entrepreneurial practices (Johannisson, 2018). As discussed above, entrepreneurial capitals (EC) are those elements of wider capitals (Bourdieu, 1990) brought into business relations and dependent on contexts for entrepreneurial activities (Hill, 2018).

Social EC is easily transformed to economic EC for Ashley: Ashley's father is wealthy and has easily accessible funds to gain a loan for the own business activities (Ta- 
ble 2, C1) with payback conditions better than banks. Ashley only has to cover living cost, as the father paid off the mortgage. Cultural to economic EC: Similarly, Ashley draws on the accountancy and information search skills gained through formal training (institutionalised cultural EC, B1) when developing business activities (cost effective supplier sourcing and price calculations), generating business income (economic EC)(Bitektine, 2011; Pret et al., 2016). Ashley also draws on attitudes towards making money developed when working in the father's business when growing up (personal structure).

Symbolic EC: Casey uses the Master's in Fine Arts (institutionalised cultural capital) when applying for contracts for creating artwork: Casey employs the degree to signal technical competence (symbolic capital), attracting paying clients (converting institutionalised cultural capital to entrepreneurial economic capital, B4). Similarly, Casey draws on appearances of the own art in international exhibitions to gain contracts (converting symbolic to economic EC)(Bitektine, 2011; Pret et al., 2016. The research finds these conversion activities are indeed practices, as they are enacted frequently in doing business (Johannisson, 2018).

The research found two functions of creating more formalised group arrangements (co-operation for strategic reasons, Bengtsson and Kock, 2000) through forming a limited company: the internal function is for operational streamlining of buying shared materials and sundries with benefits of cost savings for each individual artisan entrepreneur, indicating resource strategising (Flanagan et al., 2018; Kuhn and Galloway, 2015). The external function serves reputational and marketing/PR streamlining of the offer away from individuals to a company image towards customers. While the three artisan entrepreneurs Ashley, Billie and Casey are self-employed, they hide the limited capitals of the one-personband when interacting with customers through referring to the relational team entrepreneurial capitals under the company name $\mathrm{K}$. They all have business cards that refer to being a director of company K.; only Casey has an additional professional identity as the self-employed artist with a separate business card and internet presence. The next section explains these business solutions through the lens of interpersonal entrepreneurial capital conversions.

Dynamic relational collaborations through the lens of inter-personal entrepreneurial capital conversions - situated entrepreneurial practices

While not formally arranged, roles have emerged for the three artisan entrepreneurs within the company $\mathrm{K}$ as a result of closely working in this small space studio $\mathrm{X}$, based on different entrepreneurial cultural capitals (see appendix for Table 3, B1): Billie leads on social media and online activities, customer interaction and workshop sales for company $\mathrm{K}$. The role includes keeping everyone on track for company operations and organising workshop 
distribution over weekends. Ashley manages administration and finances, and leads the weekly informal strategy discussions. Casey is the technical skills and craft expert and carries out studio repairs and decorating; Casey also maintains external relationships (including with the site manager). This seemingly comprehensive summary, however, does not explain, how these social relations work as effective ways of organising doing business. Simply stating each artisan entrepreneur is self-employed and has roles in the shared company does not explain how they draw on each other's expertise. The lens of entrepreneurial capital conversions between artisan entrepreneurs allows adding the needed detail to explain the workings of these situated relationships.

Table 3 (see appendix) demonstrates through indicative quotes how the case study artisan entrepreneurs draw on and transform each other's entrepreneurial capitals (ECs), extending Pret et al.'s insights (2016) to the group level within a given material context. These conversions constitute entrepreneurial practices (Johannisson, 2018; Thompson et al., 2020), that is iterative entrepreneurial behaviours frequently carried out in the course of doing business in studio $X$.

Entrepreneurial cultural capital (ECC) to symbolic and cultural capital - between Casey and Ashley: Ashley regularly draws on Casey's experience with materials and the accredited fine arts skills through a university Master's degree when talking to clients. Whenever customers need advice, Ashley and Billie ask for Casey's input on options how to address customer ideas or solve problems with art materials (C2). The researcher has seen this behaviour frequently during site visits. When Ashley was with customers and felt unable to answer a question arising, Ashley contacted Casey in person or by phone. Sometimes, the answer to the customer was delayed, when Casey was unavailable. The implicit shared understanding underlying these above actions by Ashley and Casey is that Casey holds valuable ECC within the team, which Ashley (and Billie) can access when needed.

The quote in C2 (Table 3) illustrates Casey's view on how intense this situation was and the way she was drawn into Billie and Casey 's entrepreneurial activities, when she was living close to the studio: she was called frequently to come to the site additionally 300 times. Before moving into studio $X$, such exchanges rarely happened. Furthermore, the quotes in Table 3 demonstrate the contextual significance of Casey's expertise (entrepreneurial cultural capital, ECC) for Ashley's and Billie's 'doing business'. This meaning is co-created with customers through ongoing interaction between Ashley, Billie and Casey and customers on technical matters relating to materials, indicating the sociomaterial nature of these working relationships (Orlikowski, 2007). This relational learning (KarataşÖzkan, 2011) has resulted in a practice of 'enacting Casey's expertise/entrepreneurial cultural capital'. 
Through integrating Casey's expertise - entrepreneurial cultural capital - Ashley and Billie overcome their own limited entrepreneurial cultural capital and draw on the relationally held entrepreneurial cultural capitals situated between them in social relations. These repetitive activities of "seeking advice" are based on a shared understanding of the role of Casey's entrepreneurial cultural capitals, Ashley has improved her entrepreneurial cultural capital nominally towards customers and enacts it relationally in conversations with them. Thus, the locus of this entrepreneurial cultural capital (Casey's skills and experiences with materials) is at the meso-level between the three artisan entrepreneurs (Hill, 2018). The sociomateriality of studio $\mathrm{X}$ generates the practice of doing business through company $\mathrm{K}$ (Gherardi, 2012; Johannisson, 2018), in which Casey's expertise is an essential shared cultural capital.

Entrepreneurial cultural to economic capital — from Ashley and Billie to Casey (see Table 2 C3). Ashley's accounting and strategy skills and Billie's customer understanding and social media skills (entrepreneurial embodied cultural capitals) were converted to entrepreneurial economic capital for Casey: one of Casey's technical skills (institutionalised cultural capital) was converted into offering workshops for customers learning this skill to create decorations and crockery. The quotes illustrate two angles of the same entrepreneurial behaviour and demonstrate some shared and some slightly differing meanings. The differences in the understanding are not important for the outcome - Casey started to offer customers these workshops, generating additional income (worth several thousand pounds annually). How did the workshop offer come about? Using entrepreneurial capital conversions allows to reveal the sociomaterial dynamics.

Casey was happy to acknowledge the lack of insight into the value of the own skills set (entrepreneurial cultural capital) to see workshops on training others as business opportunity. Ashley and Billie were convinced such a workshop in which Casey's would train others in her rare technical skill (entrepreneurial cultural capital and entrepreneurial symbolic capital for the rareness of the skill) would be in demand and generate a lot of money (entrepreneurial economic capital). Looking at the conversions from Casey's viewpoint, the social capital enacted continuously through the ongoing relations with Ashley and Billie brought about the suggestions for running workshops, and Casey transformed the ECC into individual income (entrepreneurial economic capital).

Entrepreneurial social to economic capital - From Ashley to Billie via company $\mathrm{K}$ The example of social capital to economic capital between Ashley and Billie via the company $\mathrm{K}$ is more obvious. All three artisan entrepreneurs share the understanding of the formalised relationship through the limited company. Thus, it might seem unsurprising that Ashley used personal social capital to bring some money into the shared business to secure a business loan: Ashley's father lent cash to the company (creating entrepreneurial 
economic capital, Hill, 2018). The money was lent by company K. to Billie as a self-employed artisan entrepreneur for business use to buy some extra small machines. These machines allowed Billie to increase customer numbers in workshops and to rent these machines out by the hour, generating more income (entrepreneurial economic capital).

Looking at the conversions from Billie's viewpoint, Billie enacted social capital held relationally with Ashley, to gain an interest-free investment into the own business. Thus, the economic gains are saving money on interest and gaining more income. Through being closely together in studio X, Ashley was doing the accounts for all three artisan entrepreneurs (entrepreneurial cultural capital), Ashley gained insights into Billie's turnover and co-created with Billie and Casey a solution to increase Billie's income, as explained above. Thus, Ashley transformed her entrepreneurial social and cultural capitals into Billie's economic capitals. While this instance of entrepreneurial activities is an example of cooperation (Kuhn and Galloway, 2015), the detail of how their cooperation works cannot be sufficiently explained with existing approaches. The relational use of Ashley's social capital to bring in entrepreneurial economic capital to company $\mathrm{K}$ happens for the third time, which qualifies this entrepreneurial activity as a practice: The sociomateriality of studio X (Gherardi, 2012) enabled such a practice to be enacted.

To sum up, the move for the artisan entrepreneurs to studio $X$ is possibly only a small physical change in studio location of a few metres, as all three of them had been within the Creative for eight years in two separate studios. However, the new shared studio changed the social relations between Ashley, Billie and Casey, as they work simultaneously next to each other for several days per week; in other words, the changed sociomateriality generated different entrepreneurial practices.

\section{Discussion}

This research aimed to understand in more detail how artisan entrepreneurs draw on social and material contexts to organise entrepreneurial activities. What was surprising was that even though the three artisan entrepreneurs Ashley, Billie and Case were co-located within the Creative for eight years in two different studios and knew each other prior to sharing studio $X$ within the Creative, they only intensified their working relationships after the move. The research analysed the ethnographically generated data of entrepreneurial activities of artisan entrepreneurs through the fine-grained lens of entrepreneurial capital conversions to be able to explain how doing business changed. Several entrepreneurial practices emerged from the changed sociomateriality (Gherardi, 2012; Orlikowski, 2007) of the studio move.

The impact of the changed sociomaterial contexts is significant: The most surprising insight was how the intense exchange relations were enabled through moving together 
into one studio. Thus, the 'material' of studio $X$ directly affected entrepreneurial activities. This research on studio space $X$ and the many entrepreneurial activities carried out within it simultaneously revealed many exchanges between Ashley, Billie, Casey and Finley, illustrating how the 'material' impacts on social relations. Some of these ongoing exchanges materialised in forming the limited company $\mathrm{K}$. These exchanges went far beyond the cooperation between artisan entrepreneurs discussed (Flanagan et al., 2018; Kuhn and Galloway, 2015). The lens of entrepreneurial capital conversions allowed the researcher to discover that resources were not only converted by individuals (intrapersonal) (Pret et al., 2016), but how sharing a limited studio allowed these artisan entrepreneurs to temporarily draw upon and convert each other's relationally held assets (entrepreneurial capitals, Hill, 2018) for developing entrepreneurial activities within the Creative. Thus, the research explained how these situated social relations influence organising entrepreneurial activities.

The limited space of studio $X$ allowed the relationships to intensify and bring forward the temporary repetitive interpersonal exchanges in organised ways. The lens of capital conversions offers a looking-glass into the dynamics of these collaborations. These interpersonal conversions most likely happen across small organisation like the Creative, illustrating the potential wider benefits of this research for entrepreneurial ecosystems (Stam and Spigel, 2017).

The research found two important functions of creating more formalised group arrangements through a limited company: the internal operational streamlining of buying shared materials and sundries with benefits of cost savings for each individual artisan entrepreneur (Flanagan et al., 2018), and the external reputational and marketing/PR streamlining of the offer, away from individuals to a company image presented to customers. While it might be overlooked, these positive effects only became enacted since these three artisan entrepreneurs share one studio. Consequently, the material environment of the studio space has had an immense effect on social relations development between the three artisan entrepreneurs. Furthermore, studio $X$ enables them to run workshops for customers due to its larger size: the two separate studios they were in before could not accommodate training customer groups to create decorative goods. To sum up, studio $X$ has become an important organising force for daily doing business directly through offering space for workshops (increased economic opportunities for income generation) and enabling the three artists to work next to each other at the same time in the same space. The latter has had a positive effect on their individual and collaborative business activities. When needed, Ashley, Billie and Casey support each other when running workshops. 
The article offers several theoretical contributions to entrepreneurship and the entrepreneurship-as-practice literature. The first contribution lies in extending existing conceptualisations of Bourdieu's capitals and their intra-personal conversions (Pret et al., 2016; Vershinina et al., 2011) to the group and inter-personal level: it discusses in detail interpersonal capital conversions in the context of situated entrepreneurial activities. This research was able to de- and re-construct how artisan entrepreneurs engage in entrepreneurial capital conversions at the group level. These conversions are temporary and contingent on the sociomateriality. They emerge as strategic tactics through the situated temporary interactions between the artisan entrepreneurs and with customers. These inter-personal entrepreneurial capital conversions were demonstrated through unpacking how these artisan entrepreneurs strategise their daily business organising. For example, Ashley uses Casey's technical expertise (entrepreneurial cultural capital) to position the own professionalism towards customers visiting the studio, compensating for the own limited technical expertise (entrepreneurial cultural capital). This insight contributes to the deconstruction of how situated practices emerge, meeting the need for research to present the world of field agents through their eyes (Johannisson, 2018). Such an insight into entrepreneurial capital conversions pushes further the existing conceptualisations of relational capitals and makes the relational nature much clearer (Hill, 2018; Pret et al., 2016). These insights demonstrate the agentic work of entrepreneurial capital transformations and the need to study micro-processes with ethnographic methods to offer a more nuanced fine-grained understanding of situated practices (Thompson et al., 2020). In addition to other studies (Pret et al., 2016), this article shows insights, which are indeed of value for business (support) practitioners and entrepreneurs.

While this research focused on artisan entrepreneurs, other self-employed professionals who work in large shared workspaces can benefit from these nuanced ways of daily organising business activities as demonstrated through the formation of company $\mathrm{K}$. These insights have relevance for discussions of the future of work (Deloitte, 2019) through offering possible strategic solutions for temporary group arrangements. These solutions have benefits for cost savings (internal) and bidding for contracts (external), demonstrating the image of a company towards customers, a co-opetition (Bengtsson and Kock, 2000). Thus, this study revealed new insights into the internal strategic benefits of forming a company for a group of self-employed artisan entrepreneurs - these findings go beyond existing insights (Flanagan et al., 2018). Company formation creates a framework for group-held entrepreneurial capitals that can then be transformed to individual outcomes as the findings showed, for example for creating economic entrepreneurial capital for Billie. 
This research draws on Berger and Luckmann (1966) who argue that new shared meanings are collectively and interactively created and maintained. The shared passion for crafts and mutually supportive approach to doing business (Kuhn and Galloway, 2015) is not invalidated through such strategic behaviour. The research findings in this article can add that the featured company formation is one possible materialisation of the well-established insight on mutually supportive approaches in doing business. The benefits from the collaborative working (cost savings and efficiency) do not happen automatically, but only if the social relations are managed carefully. The example of the three artisan entrepreneurs maintaining company $\mathrm{K}$ have shown how this temporary "fixing" of relationships through a company and organised processes can work. Such an insight on temporary solutions also supports the temporary situated nature of capital conversions (Hill, 2018), which the next contribution focuses on.

The second contribution is to increase attention to the fact that these capital conversions are contingent on material and social context. Sociomateriality (Orlikowski, 2007) is increasingly applied to entrepreneurship studies in a fine-grained manner. This article's research demonstrates how aspects of the material environment became core organizing principles for entrepreneurial activities and shaped social relations, and how sociomateriality affects ways of doing business. The existing theoretical literature had suggested 'context' is important (Welter et al., 2019), yet has not sufficiently explained how these microprocesses work. The formation of company $\mathrm{K}$ can be more fully explained as a result of sociomateriality; how the 'social' and 'material' impact on entrepreneurial activities can be explained to a detailed level through applying the lens of entrepreneurial capital conversions.

The third contribution is to increase attention to the nature of entrepreneurial capital (EC) conversions: their temporary and relational nature. The literature review had already pointed out the positioning of entrepreneurial capitals on the meso-level (Hill, 2018), rooted in a process-relational viewpoint. This positioning insight leads to the important requirement for artisan entrepreneurs to re-create ECs contextually at a specific point in time in a particular situation, with focus on interaction between artisan entrepreneurs, and customers and artisan entrepreneurs. This relational nature is important when considering agency in researching micro-processes of doing business. In highlighting the contingent nature of intra- and interpersonal capital conversions, this research contributes to the entrepreneurship and context literature (Welter et al., 2019).

The final contribution lies in original insights into artisan entrepreneurship (in the creative industries). While resource sharing and cooperation have been reported (Bengtsson and Kock, 2000; Kuhn and Galloway, 2015), this study added original materials and new insights into how cooperation is organised in particular settings. Company formation 
as a more permanent solution for cooperation, and forms of informal collaboration through workshop offers, have added new materials for artisan entrepreneurship studies.

Overall, this research suggests a micro-analysis of solutions for organising business activities with few resources in small spaces is not complete unless the research takes account of the micro-contexts that enable and constrain intra- and interpersonal entrepreneurial capital conversions. This research has extended the existing findings on intra-personal capital conversions (Hill, 2018; Pret et al., 2016) and considered sociomaterial contexts in its impact on inter-personal capital conversions. Through doing so, this research highlights their temporal and contingent nature. Emerging from the process-relational perspective these insights shed light on other aspects of agency in doing business in context. The author regards this focus as an important advancement of the literature, as this discussion highlights benefits of entrepreneurs' solutions to entrepreneurial activity organising that would otherwise not be plausible, for researchers and practitioners alike. For researchers, the importance of agency for studying how micro-businesses create and maintain business activities in clearly established contexts is a growing study area in entrepreneurship research.

\section{Conclusion}

The article extends the detailed understanding of artisan industry professionals' business organising activities through applying an entrepreneurial capital lens rooted in process-relational theory. The research homes in on entrepreneurial micro-processes in studio $\mathrm{X}$ in a UK creative industry organisation the Creative. The units of analysis are situated entrepreneurial activities. Some of these activities are conceptualised as relational practices that enable resource sharing and conversion. These practices are analysed in detail through the lens of entrepreneurial capital conversions. Entrepreneurial capitals are temporary manifestations of situated social relations and associated materiality. The case study of three artisan entrepreneurs sharing a studio illustrates a condensed form of strategic social relations management and forms of collaborations, which are typical of lose collaborations between creative industry professionals (Kuhn and Galloway, 2015). By contrast, the more formalised social relations management for business activities, even formalised in a limited company, is dependent on the socio-material context. This behaviour is less known. The organised strategic management of their social relations into roles is helpful for the context of emerging futures of work (OECD, 2019) not only artisan entrepreneurs can benefit from. These findings suggest that the case study's social relations management reveals some iterative patterns for which the materiality of the studio space is an organising force. 


\section{Limitations, implications and further research}

The validity of findings based on one case study with three entrepreneurs and stakeholder views might be limited because of the small number. However, the aim of this research was to expand existing understanding of situated entrepreneurial activities. For this reason, the in-depth discussion of the micro-processes in one studio space with its contingent focused practices was sufficient for illustrative purposes. More importantly, this article does not claim universal laws, but rather highlights how micro-processes are emerging in situ and how the lens of interpersonal entrepreneurial capital conversions can add insights into organising business activities.

Implications for business support focus on how site managers and business support professionals can manage relationships. Site managers should organise regularly opportunities for tenants to meet to enable informal relationship development over collaborative activities. This relationship development is beneficial for artisan entrepreneurs and as the organisation's own economic benefits. Collaborative events, such as a treasure hunt across several studios for children to find hidden objects, brings in families that will most likely buy something, either from the site shop or from artists. Similarly, different sized units and competition management - limiting the amount of offers in very similar trades - allow for more "co-opetition" (Bengtsson and Kock, 2000) and support the reported asset management, even through forming a limited company to project to outside stakeholders larger business size. Business support professionals can offer training on collaborative marketing (eg shared flyers between tenants in different studios) and show online tools to enable better collaboration in marketing and resource sharing.

Further research needs to validate this study's insights in other creative industry subsectors, organisational settings, and other industries to develop a more nuanced understanding of how socio-material contexts and their enactment shape artisan entrepreneurs doing business. Current discussions of the future of work (OECD, 2019) outline the already visible quickly increasing labour market fragmentation with more self-employment and contracting. Creative professionals, and in particular artisan entrepreneurs, have already fine-tuned various forms of temporary collaborative solutions, which offer rich ground for research for years to come.

\section{References}

Afreh, B., Rodgers, P., Vershinina, N and Williams, C. C. (2019), " Varieties of context and informal entrepreneurship. Entrepreneurial activities of migrant youths in rural Ghana”, International Journal of Entrepreneurial Behaviour \& Research, Vol. 25 No. 5, pp. 996-1013. 
Arias, R. A. C. And Cruz, A. D. (2019), "Rethinking artisan entrepreneurship in a small island. A tale of two chocolatiers in Roatan, Honduras", International Journal of Entrepreneurial Behaviour \& Research, Vol. 25 No. 4, pp. 633-661.

Bell, E., Gianluigi, M., Taylor, S. And Toraldo, M. L. (2019), “Introduction: Understanding Contemporary Craft Work”, Bell, E., Gianluigi, M., Taylor, S. And Toraldo, M. L. (Ed.'s), The organisation of craftwork. Identities, Meanings and Materiality, Routledge, New York, NY, pp. 1-19.

Bengtsson, M. and Kock, S. (2000), “'Coopetition' in business networks - to cooperate and compete simultaneously”, Industrial Marketing Management, Vol. 29 No. 5, pp. 411-426.

Berger, Peter L. and Luckmann, Thomas (1966), The social construction of reality. A Treatise in the Sociology of Knowledge, Penguin Books Ltd, London.

Berglund, K. and Wigren, C. (2014), "Ethnographic approaches to entrepreneurship and smallbusiness research: what lessons can we learn?" in Carsrud, A. L. And Braennback, M. (Eds.), Handbook of Research methods and applications in entrepreneurship and small business, Cheltenham, Edward Elgar Publishing, pp. 201-227.

Bitektine A (2011), "Toward a theory of social judgments of organizations: The case of legitimacy, reputation, and status", Academy of Management Review, Vol. 36 No. 1, pp. 151-179.

Bourdieu, P. (1990), The Logic of Practice. Stanford University Press, Stanford, CA.

Bourdieu, P. (1986), "The forms of capital", in Richardson, J. (Ed.) Handbook of Theory and Research for the Sociology of Education, Greenwood, New York, NY, pp. 241-258.

Cunliffe, A. L. and Scaratti, G. (2017). "Embedding impact in engaged research: developing useful knowledge through dialogical sensemaking", British Journal of Management, Vol. 28 No. 1, pp. 2944.

Danson, M., Galloway, L., Cabras, I. and Beatty, T. (2015), "Microbrewing and entrepreneurship: the origins, development and integration of real ale breweries in the UK", International Journal of Entrepreneurship and Innovation, Vol. 16 No. 2, pp. 135-144.

Department for Business, Energy and Industrial Strategy (2018), Industrial Strategy. Creative Industries Sector Deal, Department for Business, Energy and Industrial Strategy, London.

Eisenhardt, K. M., and Graebner, M. E. (2007), "Theory building from cases: opportunities and challenges," Academy of Management Journal, Vol. 50 No. 1, pp. 25-32.

De Clerq, D. and Voronov, M. (2009), "Toward a Practice Perspective of Entrepreneurship. Entrepreneurial Legitimacy as Habitus," International Small Business Journal, Vol. 27 No. 4, pp. 395419.

De Klerk, S. (2015),"The creative industries: an entrepreneurial bricolage perspective", Management Decision, Vol. 53 No. 4, pp. 828-842.

Dellot, B., \& Wallace-Stephens, F. (2017). The Self-organising Self Employed: Empowering grassroots collaboration in the new economy, London: Royal Society for the encouragement of Arts, Manufactures and Commerce (RSA).

Flanagan, D. J., Lepisto, D. A. and Ofstein, L. F. (2018), "Coopetition among nascent craft breweries: a value chain analysis", Journal of Small Business and Enterprise Development, Vol. 25 No. 1, pp. 2-16. 
Gedajlovic, E., Honig, B., Moore, C. B., Payne, G. T. and Wright, M. (2013), "Social Capital and Entrepreneurship: A Schema and Research Agenda," Entrepreneurship Theory and Practice, Vol. 37 No. 3, pp. 455-478.

Gherardi, S. (2012), How to conduct a practice-based study. Problems and Methods, Elward Elgar Publishing Ltd., Cheltenham.

Giddens, A. (1990), The consequences of Modernity, Stanford Stanford University Press.

Hassan, H., Tan, S.-K., Rahman, M.S. and Sade, A.B. (2017), "Preservation of Malaysian handicraft to support tourism development", International Journal of Entrepreneurship and Small Business, Vol. 32 No. 3, pp. 402-417.

Hill, I. (2018), "How did you get up and running? Taking a Bourdieuan Perspective towards a Framework for Negotiating Strategic Fit," Entrepreneurship and Regional Development, Vol. 30 No's 5-6, pp. 662-695.

Johannisson, B. (2018), Disclosing Entrepreneurship as Practice. The Enactive Approach. Edward Elgar, Cheltenham.

Karataş-Özkan, M. (2011), "Understanding Relational Qualities of Entrepreneurial Learning: Towards a Multi-layered Approach", Entrepreneurship \& Regional Development, Vol. 23 No. 9-10, pp. 877-906.

Kirstetter, K. (2012). "Insider or outsider or somewhere in between: The impact of researchers' identities on the community-based research process." Journal of Rural Social Sciences, Vol. 27 No. 2, pp. 99-107.

Kuhn, K. M. and Galloway, T. L. (2015), "With a little help from my competition: peer networking among artisan entrepreneurs", Entrepreneurship Theory and Practice, Vol. 39 No. 3, pp. 571-600.

Langley, A. And Tsoukas, H. (2017). Introduction: Process thinking, process theorising and process researching. In: Langley, A. And Tsoukas, H. (Eds). The SAGE Handbook of Process Organisation Studies. London: Sage, pp. 2-20.

Marques, Carla S., Santos, G., Ratten, V. And Barros, Ana B. (2019), "Innovation as a booster of rural artisan entrepreneurship: a case study of black pottery, International Journal of Entrepreneurial Behavior \& Research, Vol. 25 No. 4, pp. 753-772.

McKeever, E., Anderson, A. and Jack, S. (2014), "Entrepreneurship and Mutuality: Social Capital in Processes and Practices”, Entrepreneurship \& Regional Development, Vol. 26 No's 5-6, pp. 453477.

McLeod C, O'Donohoe S. And Townley B (2011), "Pot noodles, placements and peer regard: Creative career trajectories and communities of practice in the British advertising industry", British Journal of Management, Vol. 22 No. 1, pp. 114-131.

Nicolini, D. and and Monteiro, P. (2017). The practice approach: For a praxeiology of organisational and management studies. In" Langley, A. And Tsoukas, H. (Eds), The SAGE Handbook of Process Organisation Studies. London: SAGE, pp. 110-126.

OECD (2019), OECD Employment Outlook 2019. The Future of Work, OECD Publishing, Paris.

Orlikowski, W. J. (2007), "Sociomaterial practices: Exploring technology at work", Organization Studies, Vol. 28 No. 9, pp. 1435-1448.

Parry, S. (2010), "Smalltalk: rhetoric of control as a barrier to growth in artisan micro-firms", International Small Business Journal, Vol. 28 No. 4, pp. 378-397. 
Payne, G. T., Moore, G. B., Griffis, S. E. and Autry, C. W. (2011), "Multilevel Challenges and Opportunities in Social Capital Research," Journal of Management, Vol. 37 No. 2, pp. 491-520.

Pick, D., Weber, P., Connell, J., and Geneste, L. A. (2015). "Theorising creative industry management: rebooting the woolly mammoth’, Management Decision, Vol, 53 No. 4, pp. 754-762.

Pret, T. and Cogan, A. (2019), "Artisan entrepreneurship: a systematic literature review and research agenda", International Journal of Entrepreneurial Behavior \& Research, Vol. 25 (4), pp. 529-614.

Pret, T., Shaw, E. and Drakopoulou Dodd, S. (2016), "Painting the full picture: the conversion of economic, cultural, social and symbolic capital", International Small Business Journal, Vol. 34 No. 8, pp. 1004-1027.

Ram, M., N. Theodorakopoulos and T. Jones (2008), "Forms of capital, mixed embeddedness and Somali enterprise', Work, Employment and Society, Vol. 22 No. 3, pp. 427-46,

Ratten, V., Costa, C. And Bogers, M. (2019), "Artisan, cultural and tourism entrepreneurship", International Journal of Entrepreneurial Behaviour \& Research, Vol. 25 No. 4, pp. 582-591.

Reid, S. (2020), "The generative principles of lifestyle enterprising: dialectic entanglements of capital-habitus-field", International Journal of Entrepreneurial Behavior \& Research, online https:// doi.org/10.1108/IJEBR-10-2018-0688.

Schatzki, T. (2002), The site of the social: A philosophical account of the constitution of social life and change, Pennsylvania State University Press, University Park.

Scott M. (2012), "Cultural entrepreneurs, cultural entrepreneurship: Music producers mobilising and converting Bourdieu's alternative capitals", Poetics, Vol. 40 No.3, pp. 237-25

Sklaveniti, C. And Steyaert, C. (2020), "Reflecting with Pierre Bourdieu: towards a reflexive outlook for practice-based studies of entrepreneurship", Entrepreneurship and Regional Development, Vol. 32 No.'s 3-4, pp. 313-333.

Stam, E. And Spigel, B. (2017), "Entrepreneurial Ecosystems", in Blackburn, R., De Clercq, D., Heinonen, J. \& Wang, Z. (Eds.) (2017), Handbook for Entrepreneurship and Small Business, SAGE, London, pp. 407-422.

Teixeira, S. J. and Ferreira, J. J. M. (2019), "Entrepreneurial artisan products as regional tourism competitiveness", International Journal of Entrepreneurial Behavior \& Research, Vol. 25 No. 4, pp. 652-673.

Thompson, N., Verduijn, K. And Gartner, W. (2020), "Entrepreneurship-as-practice: grounding contemporary theories of practice into entrepreneurship studies", Entrepreneurship and Regional Development, Vol. 32 No.'s 3-4, pp. 247-256.

Townley, B., Beech, N. and Mckinlay, A. (2009), "Managing in the creative industries: managing the motley crew", Human Relations, Vol. 62 No. 7, pp. 939-962.

UNCTAD (2018), Creative Economy Outlook. Trends in international trade in creative industries 2002-2015. New York.

Vershinina, N. and Rodgers, P. (2019), "Symbolic capital within the lived experiences of Eastern European migrants: a gendered perspective", Entrepreneurship and Regional Development https:// doi.org/10.1080/08985626.2019.1703045. 
Vershinina, N, Barrett, R. and Meyer, M. (2011), "Forms of capital, intra-ethnic variation and Polish entrepreneurs in Leicester", Work, Employment \& Society, Vol. 25 No. 1, pp. 101-117.

Welter, F. and Gartner, W. (2016), "Advancing our research agenda for entrepreneurship and contexts", in Welter, F. and Gartner, W. (Eds.), A Research Agenda for Entrepreneurship and Context, Edward Elgar, Cheltenham, pp. 156-160.

Welter, F., Baker, T. And Wirsching, K. (2019), "Three waves and counting: the rising tide of contextualization in entrepreneurship research", Small Business Economics, Vol. 52 No. 2, pp. 319-330.

Wernerfelt, B. (1984), "A resource-based view of the firm", Strategic Management Journal, Vol. 5 No. 2, pp. 171-180.

Wigren-Kristofersen, C., Korsgaard, S., Brunding, E., Hellerstedt, K., Alsos, G. A and Grande, J. (2019), "Entrepreneurship and embeddedness: dynamic, processual and multi-layered perspectives”, Entrepreneurship and Regional Development, Vol. 31 No's 9-10, pp. 1011-1015.

Zahra, S. A., Wright, M. and Abdelgawad, S. G.( 2014), "Contextualization and the Advancement of Entrepreneurship Research”, International Small Business Journal, Vol 32 No. 5, pp. 479-500.

Appendix 
Table 2 Intra-personal capital conversions - examples of raw data*

\begin{tabular}{|c|c|c|c|c|}
\hline $\begin{array}{l}\text { A - D Capitals I } \\
\text { capitals } 1-4\end{array}$ & 1 Entrepreneurial Economic & 2 Entrepreneurial Cultural & 3 Entrepreneurial Social & 4 Entrepreneurial Symbolic \\
\hline $\begin{array}{l}\text { A Entrepreneurial } \\
\text { Economic }\end{array}$ & $\begin{array}{l}\text { So when I make any money I'll put a } \\
\text { certain amount of it away in my tax } \\
\text { account, and then I dip into it for } \\
\text { investing or when I come to pay taxes } \\
\text { it's there. }\end{array}$ & & $\begin{array}{l}\text { Ashley uses personal savings to } \\
\text { organise social outings between some } \\
\text { artisan entrepreneurs to improve the } \\
\text { relationships. }\end{array}$ & $\begin{array}{l}\text { Casey uses the successful } \\
\text { contracts won in further contract } \\
\text { bidding herself. See also B4 }\end{array}$ \\
\hline $\begin{array}{l}\text { B Entrepreneurial } \\
\text { Cultural }\end{array}$ & $\begin{array}{l}\text { Entrepreneurial cultural to } \\
\text { economic Yeah. I do that [accounts } \\
\text { and book keeping], and that's why it } \\
\text { works with the three of us because } \\
\text { I've got all of that training, all the } \\
\text { knowledge that my dad gave me } \\
\text { throughout my life about running a } \\
\text { business is just so useful [for the } \\
\text { business]. And even the economics, } \\
\text { statistics, data side of university, it's } \\
\text { just unbelievable how all of that } \\
\text { comes together. (...) }\end{array}$ & & & $\begin{array}{l}\text { Casey uses the Master's in Fine } \\
\text { Arts degree to win bids as point } \\
\text { of differentiation. [Do you } \\
\text { refer to it - Masters' in Fine Arts] at } \\
\text { all? I actually do } \\
\text { refer to it, I'll maybe say 'Well, a little } \\
\text { bit about myself. I first started doing } \\
\text { (rare skill) } 20 \text { years ago,' they go, } \\
\text { oh, } 20 \text { years. And even referring to } \\
\text { my degree (...) So l'Il talk about } \\
\text { being abroad and coming back to } \\
\text { the UK. (...) I think if I'm going to } \\
\text { meet a client for a commission } \\
\text { generally I get it. I'm quite good at } \\
\text { talking to people about stuff." }\end{array}$ \\
\hline $\begin{array}{l}\text { C Entrepreneurial } \\
\text { Social }\end{array}$ & $\begin{array}{l}\text { Social to economic Ashley "We are } \\
\text { all supported by family. If we decide to } \\
\text { borrow money we will go through the } \\
\text { process and work it out, but ultimately } \\
\text { I will borrow it from my dad because } \\
\text { it's there and it's easier and cheaper. }\end{array}$ & & $\begin{array}{l}\text { Social to social to economic (Ashley) } \\
\text { "I then met Billie at college. And Billie } \\
\text { said I'd really love to sell my stuff at craft } \\
\text { fairs, just a few bits and pieces, and I } \\
\text { said, oh, come! It's boring on your own. } \\
\text { lt's always nice to have someone there } \\
\text { to watch your stall if you need a wee. So } \\
\text { (....) we just worked together," And } \\
\text { this social contact led to successful } \\
\text { business collaborations lasting over } 10 \\
\text { years. }\end{array}$ & \\
\hline $\begin{array}{l}\text { D Entrepreneurial } \\
\text { Symbolic }\end{array}$ & $\begin{array}{l}\text { Casey refers to her exhibitions and } \\
\text { awards when bidding successfully for } \\
\text { work: \{Awards?\} I think I got Emerging } \\
\text { Artist of the Year when I lived in the } \\
\text { north, (.... ). And I'm in a collection at } \\
\text { a glass museum, in Denmark, I'm in } \\
\text { the national gallery of Scotland in } \\
\text { Edinburgh. I'm in a couple of council } \\
\text { collections as well. (...) If I'm } \\
\text { going into a school to do a - they've } \\
\text { got a big window commission that } \\
\text { they want, I'll talk about that, [last } \\
\text { Biennale] I'm in fewer shows now } \\
\text { because I don't apply as much. }\end{array}$ & & & \\
\hline
\end{tabular}

* The table needs to be read from left to right, starting with the category in the row that matches the category in the column. 
Table 3 Inter-personal capital conversions - examples of raw data*

\begin{tabular}{|c|c|c|c|c|}
\hline $\begin{array}{l}\text { A - D Capitals I } \\
\text { capitals } 1-4\end{array}$ & 1 Entrepreneurial Economic & 2 Entrepreneurial Cultural & 3 Entrepreneurial Social & 4 Entrepreneurial Symbolic \\
\hline $\begin{array}{l}\text { A Entrepreneurial } \\
\text { Economic }\end{array}$ & & $\begin{array}{l}\text { Ashley and Casey - Ashley has } \\
\text { been putting a lot of things on Etsy, } \\
\text { and selling a lot of things, Ashley } \\
\text { sent loads of things to America, (..) } \\
\text { doing really, really well (...) with one } \\
\text { particular product. So we've learned } \\
\text { from (...) this one particular product } \\
\text { that we know exactly - me and } \\
\text { Casey - know exactly what we've } \\
\text { gotta do to get the same sales but } \\
\text { we haven't done it. (...) and I know } \\
\text { that if I make this, this, this and this, } \\
\text { it is going to - and put the right tags } \\
\text { on, it's gonna sell. }\end{array}$ & $\begin{array}{l}\text { Economic to social - "When we } \\
\text { really decided to try and make } \\
\text { some money was when we were } \\
\text { approached to do DNA powder } \\
\text { initially, but then ashes in M for a } \\
\text { guy who had connections in the } \\
\text { funeral industry. He approached } \\
\text { us, we did samples and got } \\
\text { Casey on board then to help with } \\
\text { that." }\end{array}$ & \\
\hline $\begin{array}{l}\text { B Entrepreneurial } \\
\text { Cultural }\end{array}$ & $\begin{array}{l}\text { Cultural to economic and social } \\
\text { With Casey just being amazing at } \\
\text { problem solving and DIY - Casey built } \\
\text { the whole of this studio. [...] You } \\
\text { know? I couldn't have done any of } \\
\text { that, I was happy to hold the drill and } \\
\text { pass it (...) but I can't deal with } \\
\text { working that out. And then Ashley is } \\
\text { just fantastic at always being here, } \\
\text { keeping the shop open and doing all } \\
\text { the social media. }\end{array}$ & & & \\
\hline $\begin{array}{l}\text { C Entrepreneurial } \\
\text { Social }\end{array}$ & $\begin{array}{l}\text { Social to economic "But we have } \\
\text { lent Billie money to get all of the bead } \\
\text { making equipment so she can run } \\
\text { group courses. We sat down, looked } \\
\text { at all the figures, I can run a big group, } \\
\text { Casey can run a big group, but A just } \\
\text { one or two people and it really is } \\
\text { affecting the money she could earn. } \\
\text { So as a business, I lent company K } \\
\text { the money, and K lent Billie the } \\
\text { money. So it's a bit weird, but it just } \\
\text { seemed like we were all deciding that } \\
\text { that was a risk worth taking as a } \\
\text { group, rather than separating it out. } \\
\text { So definitely benefit from that, we all } \\
\text { do, I'd say. " Example } 2 \text { - Finley: "I } \\
\text { use Casey's machine if I've only got a } \\
\text { few pieces to run through, 'cause } \\
\text { she's got a much smaller machine. } \\
\text { (...) 'cause we - it's not their - they'r } \\
\text { friends as well, you see, it's not just } \\
\text { colleagues." }\end{array}$ & $\begin{array}{l}\text { Social EC to ECC from Casey to } \\
\text { Billie and Ashley: Casey: So I } \\
\text { now have a } 20 \text { minute drive to } \\
\text { decompress my brain, and also I } \\
\text { don't get called at home when I'm } \\
\text { having a day off, which used to } \\
\text { happen all the time. It was one of } \\
\text { those, 'Oh, could you just pop in? } \\
\text { There's someone who wants to talk } \\
\text { about glass.' I kept a note of it in the } \\
\text { end because it was happening so } \\
\text { often. I think there was about } 61 \\
\text { days where I didn't have a day } \\
\text { where I didn't step on site. Even } \\
\text { days off, 'can you just-?' }\end{array}$ & $\begin{array}{l}\text { Social to social to economic - } \\
\text { (Ashley) "When we really decided } \\
\text { to try and make some money was } \\
\text { when we were approached to do } \\
\text { DNA powder initially, but then } \\
\text { ashes in M for a guy who had } \\
\text { connections in the funeral } \\
\text { industry. He approached us, we } \\
\text { did samples, got Casey on board } \\
\text { then to help with that." (...) } \\
\text { Casey - And then the classes } \\
\text { have really taken off. So I'm being } \\
\text { led by the cash, really, which } \\
\text { sounds awfully materialistic, but } \\
\text { when you've been poor for } 20 \\
\text { years it's quite exciting. }\end{array}$ & \\
\hline $\begin{array}{l}\text { D Entrepreneurial } \\
\text { Symbolic }\end{array}$ & & & & $\begin{array}{l}\text { Symbolic to Social to } \\
\text { symbolic:[How do you talk to } \\
\text { footfall clients about your work, } \\
\text { what you do?] "I think that's } \\
\text { another thing, working with the } \\
\text { other two, it's easier to talk } \\
\text { about what the other person } \\
\text { does than yourself [to clients], } \\
\text { sometimes. 'Ashley will do } \\
\text { that...' And Ashley 'll do it back, } \\
\text { so that helps," }\end{array}$ \\
\hline
\end{tabular}

* The table needs to be read from left to right, starting with the category in the row that matches the category in the column. 
